\title{
Prevalence of Sarcoptes scabiei var. suis infestation in pigs of Meghalaya and its treatment
}

\author{
R. Laha ${ }^{1}$, M. Das ${ }^{1}$, P. K. Bharti², Suresh Kumar ${ }^{2}$, A. Sen ${ }^{1}$ and A. Goswami ${ }^{1}$
}

1. Division of Animal Health, Indian Council of Agricultural Research (ICAR) Complex for NEH Region, Umroi Road, Umiam, Meghalaya, India; 2. Division of Animal Production, Indian Council of Agricultural Research (ICAR) Complex for NEH Region, Umroi Road, Umiam, Meghalaya, India.

Corresponding author: R. Laha, e-mail: rglaha@gmail.com, MD: meenad3@gmail.com, PKB: pkish.1002@gmail.com, SK: suresh_vet079@rediffmail.com, AS: arnabsen123@gmail.com, AG: dranup15@gmail.com

Received: 23-08-14, Revised: 03-11-14, Accepted: 11-11-14, Published online: 29-12-2014

doi: 10.14202/vetworld.2014.1137-1139. How to cite this article: Laha R, Das M, Bharti PK, Kumar S, Sen A, Goswami A (2014) Prevalence of Sarcoptes scabiei var. suis infestation in pigs of Meghalaya and it's treatment, Veterinary World 7(12): 1137-1139.

\begin{abstract}
Aim: The aim was to study the prevalence of Sarcoptes scabiei var. suis infestation in pigs of Meghalaya and to treat the infested pigs with the chemotherapeutic agent.

Materials and Methods: A total of 196 numbers of pigs were suspected for Sarcoptes scabiei var. suis infestation maintained in both organized and unorganized pig farms as well as pigs brought for slaughter to pig slaughterhouses of Meghalaya. Deep skin scrapings were collected from all these 196 numbers of pigs. The collected scrapings were digested in $10 \%$ potassium hydroxide separately and centrifuged. The sediment portions were examined under both low and high power of the microscope to find any mite. Except the infested pigs that were brought for slaughter, all other infested pigs were treated with ivermectin@ $300 \mu \mathrm{g} / \mathrm{kg}$ body weight (b.wt) subcutaneously.
\end{abstract}

Results: Of 196 numbers of suspected pigs, 21 (10.71\%) numbers of pigs were found infested with Sarcoptes scabiei var. suis after microscopical examination of skin scrapings. Except the infested pigs that were brought for slaughter, all other infested pigs were treated successfully with ivermectin @ $300 \mu \mathrm{g} / \mathrm{kg}$ b.wt subcutaneously.

Conclusion: It can be concluded from the present study that sarcoptic mange caused by Sarcoptes scabiei var. suis is very much prevalent in pigs whether maintained in organized farms, as well as pigs maintained in unorganized way in village conditions. Pig owners should not neglect this infestation as it has economic significance. Ivermectin @ $300 \mu \mathrm{g} / \mathrm{kg}$ b.wt subcutaneously has been found to be effective to treat this infestation.

Keywords: Meghalaya, Pig, Sarcoptes scabiei var. suis.

\section{I ntroduction}

Sarcoptes scabiei var. suis infestation causes sarcoptic mange in pigs. This infestation in pigs is important because it causes economic losses to the pig owners. Pig owners generally neglect this infestation assuming its non-impact on health and production in revealed that this infestation has economic significance [1]. This economic losses to the pig owners occurs may be due to decreased growth rate, decreased fertility and lower feed conversion ratio [2,3]. S. scabiei var. suis infestation have been found as detrimental for the production performance in pigs [4-6]. In experimental S. scabiei var. suis infestations in growing pigs, a depressed mean growth rates from $9.2 \%$ to $12.5 \%$ has been recorded [7]. This mite infestation makes the pigs to rub their skin against wall, etc. leads to scratching in the skin, and the damaged skin may undergo secondary bacterial infection. This infestation may cause pig handlers itch also [8]. The research work related to sarcoptic mange infestation of pigs in under the terms of the Creative Commons Attributin License (http:// creative commons.org/licenses/by/2.0) which permits unrestricted use, distribution and reproduction in any medium, provided the work is properly cited. pig industry. However study on available literature

Copyright: The authors. This article is an open access article licensed

India is less in comparison to some other countries [9], might be its consideration as a neglected parasite. But, like other parasites, research work on sarcoptic mange in the aspects of the immunodiagnosis and molecular diagnosis using polymerase chain reaction are going on $[10,11]$. Most of the tribal population of Meghalaya reared pigs for their livelihood. As the infestation causes economic losses to the pig owners, so there is a need to study the prevalence of S. scabiei var. suis in pigs of Meghalaya maintained in organized pig farms as well as in village condition.

Keeping in view of all these adverse effects of this infestation, this present study was undertaken to know the prevalence of S. scabiei var. suis infestation in pigs of Meghalaya along with its treatment.

\section{Materials and Methods}

\section{Ethical approval}

The samples were collected as per standard sample collection procedure without harming the pigs.

For a period of 3 years (September 2010 to August, 2013), a total of 196 numbers of skin scrapings of pigs, suspected for $S$. scabiei var. suis infestation, were collected from pigs of hilly region of Meghalaya maintained in organized pig farms of Indian Council of Agricultural Research (ICAR) 
Complex for $\mathrm{NEH}$ Region, maintained in village conditions in different villages of RiBhoi District of Meghalaya and pigs brought for slaughter to pig slaughter houses of Meghalaya (Table-1). Deep skin scrapings were collected from all these 196 numbers of pigs. The collected scrapings were digested in $10 \%$ potassium hydroxide separately and centrifuged. The sediment portions were examined under both low and high power of the microscope to find any mite. Except the infested pigs that were brought for slaughter, all other infested pigs were treated with ivermectin@ @ $300 \mu \mathrm{g} / \mathrm{kg}$ body weight (b.wt) subcutaneously.

\section{Results and Discussion}

Of 196 numbers of suspected pigs (Figure-1), over all 21 (10.71\%) numbers of pigs were found infested with $S$. scabiei var. suis after microscopical examination of skin scrapings (Figure-2). The prevalence of infestation was found more in organized pig farms (20.45\%) than the pigs maintained in individual houses in village condition (8.64\%). The prevalence of infestation among pigs brought for slaughter was 7.04\%. Except the infested pigs that were brought for slaughter, all other infested pigs were treated successfully with ivermectin @ $300 \mu \mathrm{g} / \mathrm{kg}$ b.wt subcutaneously.

In a study on 583 pigs of Indian Punjab, typical sarcoptic lesions were observed in $80.6 \%$ pigs and $42.76 \%$ pigs showed the presence of S. scabiei [12]. In another study, five out of 15 suspected pigs which were suffered from skin lesions showed as positive for
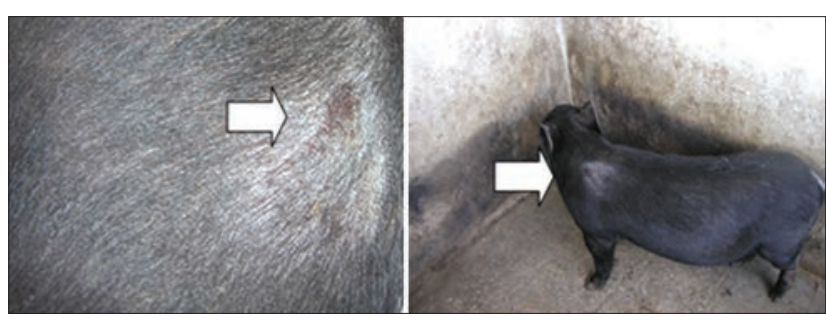

Figure-1: Skin lesions of pigs suspected for Mange infestation. the presence of $S$. scabiei var. suis infestation in an organized pig farm of Meghalaya [13]. In an organized pig farm of Assam, overall 23.61\% pigs were recorded as infested with S. scabiei var. suis [14]. A study on suspected skin lesions of pigs from Chhattisgarh revealed $37.50 \%$ pigs were affected with sarcoptic mange [15]. The pigs that were maintained in organized farm were found more infested than pigs maintained in different households in village conditions in this study. The pigs of organized farms remained in a close contact and in village condition they remained in isolated. There is a chance of spread of infestation among the pigs maintained in close contact as it has been reported that spread of mite infestation in organized farm occurred by close contact between pigs or by contact with recently contaminated surfaces [13]. Besides, the pigs of organized farms were cross bred pig. They have less resistance in comparison to local pigs that might be the reason behind higher prevalence in organized pig farm. Ivermectin @ $300 \mu \mathrm{g} / \mathrm{kg}$ b.wt subcutaneously was found suitable for the treatment of S. scabiei var. suis infestation in pigs in this study. Similarly, injection of ivermectin subcutaneously @ $300 \mathrm{mg} / \mathrm{kg}$ body weight have been used successfully for the treatment of $S$. scabiei var. suis infestation in pigs [16-18]. Injectable ivermectin was selected as a drug of choice for the treatment of S. scabiei var. suis infestation because it can be used for treatment of both internal parasitic infections and external parasitic infestations [19,20], as it has been observed that $34.00 \%$ pigs of this area are infected with gastrointestinal parasites [21].

\section{Conclusion}

It can be concluded that sarcoptic mange caused by S. scabiei var. suis is very much prevalent in pigs of the hilly region of Meghalaya, whether maintained in organized farms or maintained in unorganized way in village conditions. Pig owners should not neglect this infestation as it has economic significance. Ivermectin @ $300 \mu \mathrm{g} / \mathrm{kg}$ b.wt subcutaneously has been found to be effective to treat this infestation.

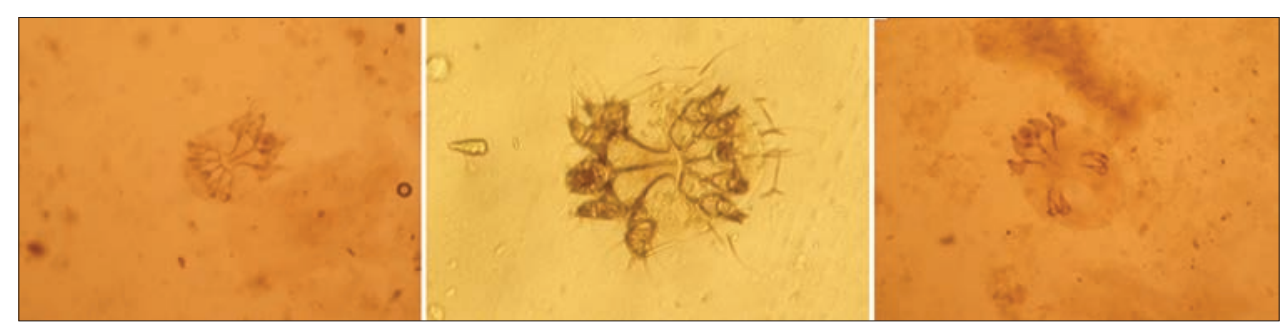

Figure-2: Diagnosis of Sarcoptes scabiei var. suis from suspected skin lesions.

Table-1: Prevalence of Sarcoptes scabiei var. suis infestation in pigs from various sources.

\begin{tabular}{|c|c|c|c|c|c|c|c|}
\hline \multicolumn{2}{|c|}{ Organised Farms } & \multicolumn{2}{|c|}{ Villages } & \multicolumn{2}{|c|}{ Slaughter house } & \multicolumn{2}{|c|}{ Total } \\
\hline $\begin{array}{l}\text { Nos. of pigs } \\
\text { examined }\end{array}$ & $\begin{array}{l}\text { Nos. of pigs } \\
\text { positive }(\%)\end{array}$ & $\begin{array}{c}\text { Nos. of pigs } \\
\text { examined }\end{array}$ & $\begin{array}{l}\text { Nos. of pigs } \\
\text { positive }(\%)\end{array}$ & $\begin{array}{c}\text { Nos. of pigs } \\
\text { examined }\end{array}$ & $\begin{array}{l}\text { Nos. of pigs } \\
\text { positive }(\%)\end{array}$ & $\begin{array}{l}\text { Nos. of pigs } \\
\text { examined }\end{array}$ & $\begin{array}{l}\text { Nos. of pigs } \\
\text { positive }(\%)\end{array}$ \\
\hline 44 & $9(20.45)$ & 81 & $7(8.64)$ & 71 & $5(7.04)$ & 196 & $21(10.71)$ \\
\hline
\end{tabular}




\section{Authors' Contributions}

RL designed the experiment, collected and processed samples, treated animals, prepared revised manuscript and also worked as a corresponding author. PKB and SK collected samples from organized farm and treated animals. MD collected and processed samples, treated animals. AG collected references. AS prepared manuscript and participated in scientific discussion. All the authors read and approved the final manuscript.

\section{Acknowledgments}

Authors are thankful to the Director, ICAR Research Complex for NEH Region, Umroi Road, Umiam, Meghalaya - 793 103, for providing the facilities and fund for this study under Institute project entitled "Detection of mange infestation in pigs of Meghalaya."

\section{Competing I nterests} interests.

The authors declare that they have no competing

\section{References}

1. Damriyasa, I.M., Failing, K., Volmer, R., Zahner, H. and Bauer, C. (2004) Prevalence, risk factors and economic importance of infestations with Sarcoptes scabiei and Haematopinus suis in sows of pig breeding farms in Hesse, Germany. Med. Vet. Entomol., 18(4): 361-367.

2. Zimmermann, W. and Kircher, P. (1998) Serologische bestandesuntersuchung und sanierungsuberwachung der Sarcoptes scabiei var. suis infektion: Erste vorlaufige resultate. Schweiz. Arch. Tierheilkd., 140(12): 513-517.

3. Mercier P., Cargill, C.F. and White, C.R. (2002) Preventing transmission of sarcoptic mange from sows to their offspring by injection of ivermectin. Effects on swine production. Vet. Parasitol., 110(1-2): 25-33.

4. Arends, J.J., Stanislaw, M.C. and Gerdon, D. (1990) Effects of sarcoptic mange on lactating swine and growing pigs. $J$. Anim. Sci., 68(6): 1495-1499.

5. Davies, R.R. (1995) Sarcoptic mange and production performance of swine: A review of the literature and studies of association between mites infestation, growth rate and measures of growth severity in growing pigs. Vet. Parasitol. 60: 249-264.

6. Elbers, A.R.W., Rambags, P.G.M., Van der Heijden, H.M.J. and Hunneman, A. (2000) Production performance and pruritic behaviour of pigs naturally infected with Sarcoptes scabiei var suis in a contact transmission experiment. Vet. Q., 22(3): 145-149.

7. Cargill, C.F. and Dobson, K.J. (1979) Experimental Sarcoptes scabiei infestation in pigs: (2) Effects on production. Vet. Rec., 104(2): 33-36.

8. Chakrabarti, A. (1990) Pig handler's itch. Int. J. Dermatol., 29(3): 205-206.

9. Laha, R. (2014) Sarcoptic mange infestation in pigs: An overview. J Parasit. Dis., DOI: 10.1007/s12639-014-0419.5.

10. Alasaad, S., Walton, S., Rossi, L., Bornstein, S., AbuMadi, M., Soriguer, R.C., Fitzgerald, S., Zhu, X.Q., Zimmermann, W., Ugbomoiko, U.S., Pei, K.J.C. and Heukelbach, J. (2011) Sarcoptes-world molecular network (Sarcoptes - WMN): Integrating research on scabies. Int. J. Infect. Dis., 15(5): e294-e297.

11. Hejduk, G., Hofstatter, K., Lowenstein, M., Peschke, R., Miller, I. and Joachim, A. (2011) Characterisation of Sarcoptes scabiei antigens. Parasitol. Res., 108: 309-315.

12. Gill, B.S., Singh, J., Gill, B.S. and Khera, S.S. (1990) Efficacy of ivermectin against mange and gastrointestinal nematodes of pigs and goats. Indian. J. Parasitol., 14: 93-98.

13. Das, M., Laha, R., Devi, P., Bordoloi, R.K. and Naskar, S. (2010) Sarcoptic mange infestation in pigs in a hilly region of Meghalaya. Trop. Anim. Health Prod., 42(5): 1009-1011.

14. Rajkhowa, S., Das, A., Baruah, R.K., Kalita, C. and Das, J.P. (2012) Prevalence of mange mite infestation in an organized pig farm and its management. In Compendium of XXIII National Congress of Veterinary Parasitology and National Symposium on "Parasitology Today: From Environmental and Social Impact to the application of Geoinformatics and Modern Biotechnology" held in the Department of Parasitology, College of Veterinary Science, Assam Agricultural University, Khanapara, Guwahati-781 022, Assam from $12^{\text {th }}$ Dec. to $14^{\text {th }}$. Dec. 2012. p. 55.

15. Maiti, S.K., Chourasia, S.K., Gadpayle, R.K. and Sharma, N. (2004) Treatment of Sarcoptic mange in pigs with Cypermethrin. Indian Vet. Med. J. 28: 380.

16. Seamen, J.T., Thompson, D.R. and Barrick, R.A. (1993) Treatment with ivermectin of sarcoptic mange in pigs. Aust. Vet. J., 70(8): 307-308.

17. Arends, J.J., Skogerboe, T.L. and Ritzhaupt, L.K. (1999) Persistent efficacy of doramectin and ivermectin against experimental infestations of Sarcoptes scabiei var. suis in swine. Vet. Parasitol., 82(1): 71-79.

18. Chellapandian, M., Ramprabhu, R. and Balachandran, S. (2004) Treatment of sarcoptic mange with ivermectin. Indian Vet. J., 81: 1051-1052.

19. Saeki, H., Fujii, T., Fukumoto, SI., Kagota, K., Taneichi, A., Takeda, S. and Tsukaguchi, M. (1996) Efficacy of doramectin against intestinal nematodes and sarcoptic mange mites in naturally infected swine. J. Vet. Med. Sci., 59(2): 129-132.

20. Yazwinski, T.A., Tucker, C., Featherston, H., Johnson, Z. and Wood-Huels, N. (1997) Endectocidal efficacies of doramectin in naturally parasitized pigs. Vet. Parasitol., 70(1-3): 123-128.

21. Laha, R., Das, M., Goswami, A., Sen, A., Kumar, S. and Kadirvel, G. (2014) Epidemiology of gastrointestinal parasitism in pigs in subtropical Hill Zone of Meghalaya. Indian J. Hill Farming, 27: 101-109. 